\title{
The electron microprobe analysis of agglutinating foraminifera; results from a Rotaliammina test from the S.W. Pacific
}

\author{
JENNIFER C. BEVAN \\ Department of Mineralogy, British Museum (Natural History), \\ Cromwell Road, London SW7 5BD.
}

\begin{abstract}
Electron microprobe analyses and element distribution images of a Rotaliammina test from Funafuti, S. W. Pacific, are presented. Detailed analysis of both spiral and umbilical surfaces shows that the earliest chambers are richest in organic components, and that the brown coloration of the test correlates with amount of organic material ("tectin") rather than with iron content. The peripheral flange is shown to be similar in composition to the agglutinant-rich spiral surface of the last chamber. The example serves to illustrate a usefui analytical method which has application to the study of the structure and composition of the wall of agglutinating foraminifera in general.
\end{abstract}

\section{INTRODUCTION}

The application of the electron microprobe to the study of the composition and structure of the agglutinating foraminiferal wall has great potential in the classification of this rather neglected group. Several genera and species have been examined using the method described below, in the context of taxonomic studies of trochamminacean foraminifera undertaken by Dr. J. E. Whittaker (British Museum (Natural History)) and his collaborator Prof. P. Brönnimann (formerly of the University of Geneva).

An analysis is presented here of a Rotaliammina test from a suite of specimens collected by $F$. Chapman from Funafuti, Tuvalu, S.W. Pacific. It is an interesting example of what can be achieved with the method. The species of Rotaliammina is probably new but, because of the few specimens available, has been left for the moment in open nomenclature. (For further comments on the genus, see Brönnimann et al., 1983, pp. 211-214, pls. 1-3).

Two other specimens belonging to the same species and from the same sample were photographed by scanning electron microscopy ( $\mathrm{Pl} .1$, figs. 1-7). A distinctive feature of the test is the marked contrast between the smooth, tectinous umbilical surface compared with the highly agglutinated spiral surface and peripheral flange. Further discussion of its morphological features are given in the explanation to Pl. 1 .

Examination by microprobe was attempted in order to quantify any compositional variation in cement and bulk composition especially between the different sides of the test; to determine the nature of the agglutinating particles; and to examine the composition and relationship of the peripheral flange to the chambered part of the test. It was hoped thereby to form conclusions on the development of the test in this particular species.
Electron probe microanalytical techniques are particularly useful for compositional studies of the tests of foraminifera since areas for analysis are selected using high resolution electron imaging and the analytical resolution of the method is better than $5 \mu \mathrm{m}$. It is thus possible to examine in detail the different structures of the test and to avoid contaminant particles. Results of analyses of other species have been incorporated into several taxonomic papers prepared by my collaborators and presented elsewhere (e.g. Brönnimann, 1986).

\section{ANALYTICAL METHOD \\ Specimen preparation}

The specimen was mounted on a glass slide by means of a thin layer of plastic conducting carbon-loaded adhesive ("Leit-C-Plast"), which allowed the specimen to be lifted off and turned over when required. Each side of the test was coated with an approximately $200 \AA$ thick layer of carbon before analysis to render it conductive.

\section{Analysis}

The analyses were made using a Cambridge Instruments "Microscan 9" automated wavelength-dispersive electron probe microanalyser. The operating conditions were: accelerating voltage $-20 \mathrm{kV}$; specimen current (on Faraday cage) $-2.5 \times 10^{-8} \mathrm{~A}$; incident angle $-90^{\circ}$; take-off angle $-75^{\circ}$; counting time -10 seconds. Standards of analysed minerals and pure metals were used and the results were corrected for atomic number, absorption and fluorescence effects.

All the analyses (Table 1) represent "point" analyses using a beam of approximately $1 \mu \mathrm{m}$ diameter for which the analytical resolution is approximately $5 \mu \mathrm{m}$. The $\mathrm{X}$ ray scanning images (Pl. 1, figs. 8, 10-13) were obtained under the above operating conditions using the hybrid scan facility and variable scan exposure times. 


\section{RESULTS}

Representative analyses are given in Table 1, four from the umbilical surface, five from the spiral surface and two from the peripheral flange, each on opposite sides of the test. They are quoted as weights percent of oxides since in geochemistry it is conventional for analyses of minerals which contain oxygen to be presented in this way. Oxygen itself is rarely determined, but the amounts of oxygen in combination with the various cations present can be assumed from valency considerations and, for most minerals, the sum of the oxides is a correct representation of the mineral composition. An analysis of calcium carbonate $\left(\mathrm{CaCO}_{3}\right)$, for example, can be expressed as weights percent of $\mathrm{CaO}$ and $\mathrm{CO}_{2}$.

This method of presentation is not normally applied to organic compounds containing complex linkages; however, it has been retained here for the partial analyses of the organic compound-bearing test material in order to facilitate comparisons with inorganic material.
Sodium and chlorine were present in small amounts (less than $0.8 \%$ ) but are not included in Table 1 since it is likely that they are derived from contamination (seawater, glue from the microslide, or handling). Iron (as $\mathrm{FeO}$ ) was close to, or below detection limits in some parts of the test and was nowhere found in amounts greater than 0.5 weight percent. In analysing the flange and the spiral surface in general, an attempt was made to analyse the cement of the test rather than individual agglutinated mineral grains alone, as investigations of the latter had shown many of them to be composed largely of calcium carbonate. Exceptions, however, were provided by the flange and the last chamber which tended to be very variable in composition.

\section{DISCUSSION \\ Previous work}

There is little published work on foraminiferal test composition using electron probe microanalytical techniques, apart from Hooper's (1964) exploratory study.

\section{Explanation of Plate 1}

\section{Rotaliammina sp.}

Figs. 1-3, 6. BMNH No. ZF4264, spiral, oblique-umbilical and umbilical views and detail of early enrolment: figs. 1-3, $\mathrm{X} 145$; fig. $6, \mathrm{X} 1,000$.

Figs. 4, 5, 7. BMNH No. ZF4265, spiral oblique-umbilical and umbilical views, X145.

Figs. 8-13. BMNH No. ZF 4266: figs. 8, 11, calcium and sulphur X-ray scanning micrographs of spiral side, X 115; figs. $9,10,12,13$, backscattered electron micrograph and calcium, sulphur and magnesium $X$-ray scanning micrographs of umbilical side respectively, X 115. (N.B. The size difference between the umbilical and spiral images is a result of loss of the peripheral flange when the specimen was turned).

All specimens from off Tutanga, Funafuti, Ellice Islands (Tuvalu), S. W. Pacific. Depth 50-60 fathoms $(92-110 \mathrm{~m})$. Ex F. Chapman Collection.

The peripheral flange is well developed in all three specimens, although some of it has broken off. There is no Puffersubstanze nor Toga (in the sense of Rhumbler, 1938) and there is no amorphous substance as found in Rotaliammina mayori Cushman, the type-species. The umbilical views show the mushroom-shaped, somewhat overlapping chambers with the single axially-directed aperture. The axial depression is subcircular, deep and open. The chamber walls are smooth, consisting of organic substance with very little or no agglutinant. The radial septa, on the other hand, exhibit the same agglutinated texture as the spiral surface of the chambers. Apart from the proloculus and deuteroloculus (fig. 6), which have a smooth organic chamber wall, the spiral views show a strongly agglutinated surface. The peripheral flange seems to be rather less agglutinated than the chamber walls, however. The sutures are well defined and the individual chambers well differentiated. In all specimens the final whorl consists of nine chambers, while the total number of chambers is about thirty, arranged in three to four whorls. Although showing some affinities to both $R$. siphonata (Seiglie) and $R$. mayori auct., this species is probably new, but for the present is left in open nomenclature.

Of the X-ray scanning micrographs, figs. 8 and 10 show the calcium content which is high on the spiral side (fig. 8) and on the radial septa and peripheral flange of the umbilical side (fig. 10). The umbilical chamber walls show, with the exception of the ultimate wall which was probably slightly uplifted, less calcium than the remainder of the umbilical side. Magnesium is low in concentration on the umbilical side but correlates inversely, albeit at a lower concentration, with calcium (fig. 13). Also on this side, the sulphur content (fig. 12) shows a higher concentration over the essentially organic chamber walls than over the radial septa, peripheral flange and strongly agglutinated ultimate chamber. The sulphur micrograph of the spiral side (fig. 11) shows a greater concentration of this element in the central part of the test where the early chambers have higher contents of organic material. 


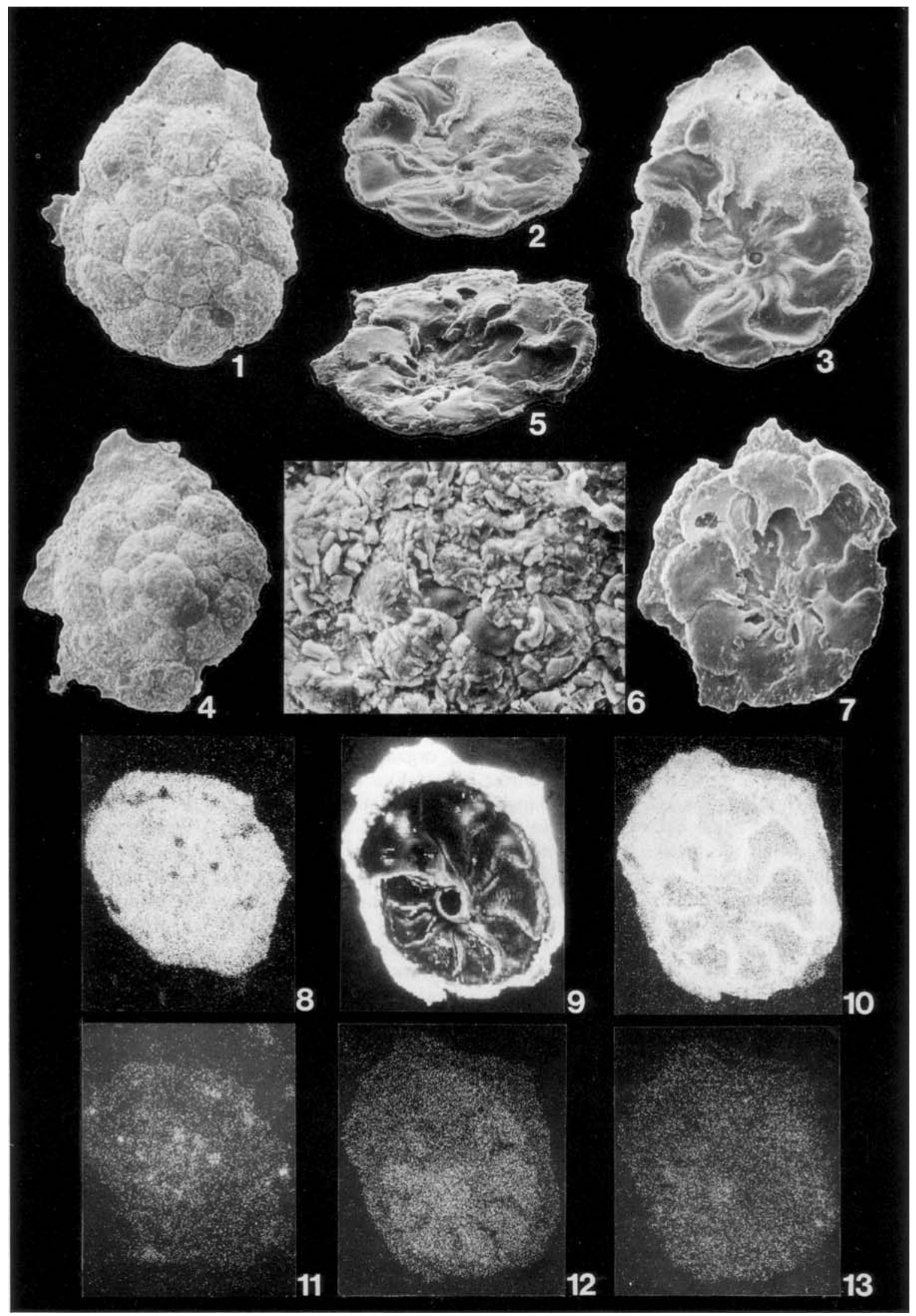


Table 1. Partial quantitative analyses of a Rotaliammina test (in weights percent of oxides)

\begin{tabular}{|c|c|c|c|c|c|c|c|c|c|c|c|}
\hline \multirow[b]{2}{*}{ Chamber: } & \multicolumn{4}{|c|}{$\begin{array}{l}\text { UMBILICAL } \\
\text { SIDE }\end{array}$} & \multicolumn{5}{|c|}{$\begin{array}{l}\text { SPIRAL } \\
\text { SIDE }\end{array}$} & \multicolumn{2}{|c|}{$\begin{array}{l}\text { PERIPHERAL } \\
\text { FLANGE }\end{array}$} \\
\hline & 2 & 3 & 7 & 9 (last) & 1 (prol.) & 5 & 14 & 23 & 29 (last) & (A) & (B) \\
\hline $\mathrm{SiO}_{2}$ & 0.2 & 0.3 & 0.2 & 4.6 & 0.1 & 0.1 & 0.1 & 0.1 & 0.9 & 0.3 & 0.3 \\
\hline $\mathrm{Al}_{2} \mathrm{O}_{3}$ & 0.2 & 0.3 & 0.3 & 1.1 & 0.1 & 0.1 & 0.1 & 0.2 & 0.3 & 0.2 & 0.2 \\
\hline $\mathrm{MgO}$ & 1.8 & 2.1 & 2.0 & 1.2 & 1.3 & 0.4 & 1.3 & 0.4 & 3.8 & 0.3 & 0.3 \\
\hline $\mathrm{CaO}$ & 11.5 & 12.3 & 18.5 & 23.9 & 6.4 & 36.9 & 39.0 & 51.7 & 42.6 & 42.7 & 40.2 \\
\hline $\mathrm{K}_{2} \mathrm{O}$ & 2.3 & 3.0 & 1.8 & 2.0 & 1.0 & 1.0 & 1.3 & 0.5 & 0.6 & 0.9 & 0.9 \\
\hline $\mathrm{P}_{2} \mathrm{O}_{5}$ & 4.5 & 6.6 & 5.3 & 5.0 & 2.1 & 2.5 & 2.3 & 2.1 & 2.1 & 2.4 & 2.2 \\
\hline $\mathrm{SO}_{2}$ & 5.1 & 5.3 & 5.2 & 3.6 & 3.8 & 2.1 & 3.5 & 0.8 & 1.1 & 1.0 & 1.1 \\
\hline
\end{tabular}

(Analyses A and B are of different areas of the flange.)

Quantitative analysis was not attempted with the apparatus available at that time but scanning X-ray imagery and scan profiles gave information on the composition of the tests of five different foraminifera. Although the tests that Hooper examined were largely calcium carbonate, the presence and distribution in them of magnesium, sulphur, iron and manganese were demonstrated. Lipps \& Ribbe (1967) measured trace amounts of magnesium, iron and strontium in a number of planktonic foraminifera using the microprobe; they considered that the presence of other trace elements was due to contamination.

The ion probe, a related technique, can give information on isotopic composition as well as a chemical analysis. It is, however, a destructive method, unlike the microprobe which leaves the specimen unchanged for future work. Vénec-Peyré (1980) used the ion microprobe to show that the areas of substitution of calcium by strontium, sodium and magnesium in certain foraminiferal tests are related to their lamellar structure. Previously published ion-probe studies include those of Very \& Le Campion (1976), Lefèvre \& Vénec-Peyré (1977) and Vénec-Peyré \& Jaeschke-Boyer (1978).

Bulk analyses of foraminiferal tests by various analytical methods have been available since the late nineteenth century; Hedley (1963) gives a good review of early analytical work with special reference to iron contents and cement composition, and gives partial analyses of four species of siliceous agglutinating foraminifera. Bender et al. (1975) reviewed the calcite chemistry of foraminifera and analysed many specimens by neutron activation techniques; minor and trace elements present included sodium, magnesium, aluminium, chlorine and strontium.

\section{This study}

Most analysts stress the importance of careful specimen preparation in obtaining valid analytical results.
Contamination by extraneous material on the surface or within the chambers of the test may be difficult either to observe or remove before bulk analysis. However, the microprobe makes it possible not only to distinguish contaminant grains, but also to avoid them during analysis. In addition, the nature of different parts of the test and individual compositions of agglutinated particles can be determined.

The analyses given above were made on the surface of the test, although excitation extends to a depth of $2 \mu \mathrm{m}$ or more. Both X-ray scanning images (Pl. 1, figs. 8, 10-13) and partial analyses (Table 1) show that sulphur and magnesium are associated with the calcium-poor organic cement. The presence of cement is also shown on the backscattered electron scanning images (e.g. Pl. 1, fig. 9) used to locate areas for analysis, since areas with the highest average atomic number will reflect more electrons, and thus appear brighter, than those with low average atomic numbers. Cement, composed predominantly of elements of low atomic number, always appears darker than the largely inorganic agglutinated grains.

Umbilical side. Except for the septa which appear to have agglutinated material adhering to them, the umbilical surface of the species of Rotaliammina from Funafuti (Pl. 1, figs. 2, 3, 5, 7, 9) is smooth and has a high content of organic material (compare Pl. 1, fig. 12 (sulphur) and Pl. 1, fig. 13 (calcium) and analyses in Table 1). It is possible that the agglutinated material of the septa represents a portion of the flange which extended over each last-formed chamber and, as new chambers formed, a remnant of flange was incorporated into the test along each septum. There appears to be an increase in the inorganic component of the chamber wall material with ontogeny.

Spiral side. Pl. 1, figs. 1, 4, 6 show the spiral surface of the Rotaliammina test from Funafuti to be largely composed of agglutinated material, similar in nature to 
the flange. However, analyses and X-ray scanning images (Table 1 and $\mathrm{Pl} .1$, figs. 8,11 ) demonstrate that the proloculus and early chambers are richer in organic material than the later chambers, which compare with a similar variation seen in the unagglutinated umbilical chamber walls during ontogeny. The darker brown appearance under the optical microscope of the central part of the test the refore correlates with organic content, either in the cement and/or as an inner organic lining, rather than with iron content as has been suggested for other agglutinating foraminifera.

Hedley (1963) discussed the composition of organic cement in arenaceous foraminifera. He concluded that, in the species he examined, the cement is a mucosubstance containing acid mucopolysaccharide to which iron, and possibly calcium is organically bound. Mineralisation of the cement, during or after chamber formation by calcium and/or iron inorganic compounds, will produce hard shells, whereas unmineralised shells remain soft. The test of the Rotaliammina has been mineralised by calcium carbonate and other inorganic compounds as shown in Table 1. Iron, however, does not appear to be present in this species as a significant component of the cement although even trace amounts may have some significance in the process of mineralisation.

Further discussion is presented in the explanation to Pl. 1.

\section{CONCLUSIONS}

The difference in appearance between the rough spiral and smooth umbilical surfaces of the Rotaliammina test described here is accompanied by a difference in chemical composition: the chamber walls of the umbilical side are rich in sulphur and magnesium-bearing organic compounds, whereas the agglutinant-rich spiral surface is largely calcium carbonate.

In addition, there is a decrease in content of organic material in the chamber walls with ontogeny, indicating that the compositions now are probably the same as those obtaining during life, rather than being the result of later replacement ("mineralisation") by inorganic compounds.

The proportion of organic material in the test corresponds to the degree of brown coloration; the low iron contents in this specimen neither correlate with this coloration nor indicate that iron is essential to the stablisation of the cement.

Fragments of aggluntinated material along septa on the umbilical side are similar in appearance and composition to the flange material and may represent remnants of flange trapped as new chambers were added. If so, they are evidence that the flange was present throughout the life of the foraminfer.

This electron microprobe study indicates some of the possibilities this method offers to our greater understanding of the agglutinating foraminiferal wall.

\section{ACKNOWLEDGEMENTS}

The author is indebted to Dr. J. E. Whittaker for instigating the study and for notes and discussion on the morphology of the Rotaliammina sp. Thanks are due to Dr. P. Henderson and Dr. A. C. Bishop, also of the British Museum (Natural History), for critical reading of the manuscript.

Manuscript received April 1985 Manuscript accepted May 1985

\section{REFERENCES}

Bender, M. L., Lorens, R. B. \& Williams, D. F. 1975. Sodium, magnesium and strontium in the tests of planktonic foraminifera. Micropaleontology, New York, 21, 448-459.

Brönnimann, P. 1986. On Asarotammina asarotum gen. et sp. nov., a new trochamminacean foraminifer from the Brazilian Shelf. J. foramin. Res., Washington. (In press).

Brönnimann, P., Zaninetti, L. \& Whittaker, J. E. 1983. On the classification of the Trochamminacea (Foraminiferida). J. foramin. Res., Washington, 13, 202-218.

Hedley, R. H. 1963. Cement and iron in the arenaceous foraminifera. Micropaleontology, New York, 9, 433-441.

Hooper, K. 1964. Electron probe microanalysis of Foraminifera: an exploratory study. J. Paleont., Tulsa, 38, $1082-1092$

Lefèvre, R. \& Vénec-Peyré, M.-T. 1977. Mise en évidence au microanalyseur ionique d'une zonation dans la répartition du sodium, magnésium et strontium dans la test d'un Foraminifère calcaire perforé: Ammonia beccarii (L.).C. r. hebd. Séanc. Acad. Sci., Paris, ser. D, 285, 23-26.

Lipps, J. H. \& Ribbe, P. 1967. Electron-probe microanalysis of planktonic foraminifera. J. Paleont., Tulsa, 41, 492-496.

Rhumbler, L. 1938. Foraminiferen aus dem Meeressand von Helgoland, gesammelt von A. Remane (Kiel). Kieler Meeresforsch., 2, 157-222.

Vénec-Peyré, M.-T. 1980. Microanalyseur ionique et microsonde moléculaire à laser MOLE: Application à l'étude chimique et minéralogique du test d'Ammonia beccarii (Linné), Foraminifère. Bull. Cent. Rech. Pau, 4, 55-79.

Vénec-Peyré, M.-T. \& Jaeschke-Boyer, H. 1978. Application de la microsonde moléculaire à laser MOLE a l'étude du test de quelques Foraminifères calcaires, $C$. r. hebd. Séanc. Acad. Sci., Paris, ser. D, 287, 607-609.

Very, J. M. \& Le Campion, J. 1976. Étude préliminaire de la minéralisation du test chez un Foraminifère planctonique: Orbulina universa d'Orbigny, 1839 (Protozoaire, rhizopode). In Sér, Résultats des Campagnes à la mer, 9 , 127-137 (CNEXO, Paris).

\section{NOTE ADDED IN PROOF}

Since this paper was accepted for publication, a paper describing the analysis of agglutinating foraminifera by a related technique, that of S.E.M./E.D.S., has been published: Commeau, R. F., Reynolds, L. A. \& Poag, C. W. 1985. Elemental X-ray mapping of foraminifer tests: A nondestructive technique for determining compositional characteristics. Micropaleontology, New York, 31, 380-386. 